\title{
KURIKULUM 2013: MEMENANGKAN MASA DEPAN INDONESIA
}

\author{
ARDIAN BAKHTIAR RIVAI \\ Program Pascasarjana Universitas Gadjah Mada \\ e-mail: ardian.bakhtiar@gmail.com
}

\section{INTISARI}

Makalah ini menawarkan gagasan tentang rekonseptualisasi kepada para stakeholder pendidikan di Indonesia. Kecenderungan yang muncul saat ini adalah, adanya konsep berfikir yang sangat pesimistik terhadap masa depan Indonesia. Pesimisme yang demikian itu, tak bisa dipungkiri akibat dari dinamika politik pendidikan di Indonesia yang dominan untuk diarahkan pada posisi, kerangka berfikir, dan faham yang cenderung pragmatis dan instan. Sehingga, proses menjadi terbaikan untuk mencapai tujuan pendidikan yang diinginkan. Gagasan yang dikonstruksi dalam makalah ini mencoba untuk merubah ulang tentang pemahaman yang beredar saat ini, bahwa kejayaan masa depan Indonesia bukanlah sesuatu yang mustahil. Kejayaan masa depan Indonesia merupakan sesuatu yang nyata, sesuatu yang sangat mungkin terjadi, bahkan sudah berada tepat dihadapan masyarakat bangsa ini. Dalam kerangka berfikir tersebut, makalah ini menganggap Kurikulum 2013 sebagai salah satu instrumen yang paling tepat untuk melakukan rekonseptualisasi tentang memenangkan pertarungan masa depan Indonesia. Meminjam model teori oleh Doerrer dan Pulley (1977) tentang "The Politics of Curriculum Development" yang menganggap pengembangan kurikulum sebagai sesuatu yang rasional dan proses yang sangat scientific. Dengan menggunakan teori itu, makalah ini mencoba menyimpulkan bahwa sesungguhnya pengembangan kurikulum merupakan sesuatu hal yang sangat kodrati, atau jika lebih ekstrim ditafsirkan pengembangan kurikulum adalah sebuah keharusan. Disaat yang bersamaan, makalah ini menawarkan logika tentang kurikulum 2013 sebagai instrumen untuk mengikuti perkembangan zaman dan jalan menuju kemenangan masa depan Indonesia.

Kata-kata Kunci: Kurikulum 2013, Politik Pendidikan, Masa Depan, Indonesia.

\section{PENDAHULUAN}

Memenangkan pertarungan adalah sebuah kewajiban mutlak yang diemban oleh manusia sebagai makhluk tuhan yang paling sempurna. Itulah sebabnya, makalah ini memilih untuk menggunakan judul tersebut sebagai konsep besar dalam perubahan cara berfikir yang seharusnya melekat dalam setiap benak 
masyarakat Indonesia. Perubahan cara berfikir yang dimaksud yaitu, kecenderungan mainstream berfikir masyarakat saat ini adalah lebih memilih menyalahkan kegelapan daripada menciptakan penerangan. Sehingga, istilah yang kemudian muncul adalah istilah-istilah yang bernada pesimis. Makalah ini mencoba untuk mengajak segenap para sivitas akademika untuk keluar dari kotak berfikir yang pesimistik negatif. Yakinlah bahwa, sesungguhnya masa depan Indonesia bisa dimenangkan dengan optimisme dan perubahan secara dinamis.

Kurikulum 2013 sebagai instrumen perubahan tersebut, merupakan dinamika kehidupan khususnya sektor pendidikan untuk menjawab pertanyaan besar para pendiri bangsa yang diwariskan dalam konstitusi republik ini. Mencerdaskan kehidupan bangsa ternyata bukan perkara sederhana, begitupun dengan mensejahterakan kehidupan umum, dan termasuk tanggung jawab lain yang diamanatkan kepada kita sebagai pewaris peradaban bangsa. Tanggung jawab konstitusi yang melekat dalam setiap darah orang Indonesia menjadi hutang permanen yang akan terus mengalir hingga anak cucu di masa yang akan datang. Tanggung jawab konstitusi tidak saja menjadi beban pemerintah, melainkan juga beban kita semua sebagai pewaris kolektif dari sebuah bangsa yang bernama Indonesia.

Memenangkan masa depan Indonesia bukanlah suatu mimpi, bukan juga sebuah dongeng, kemenangan masa depan bangsa ini sudah berada tepat dihadapan pasangan mata 242.325.638 (Jumlah Penduduk Indonesia versi World Bank, 2011). Tanggung jawab untuk memenangkan masa depan bangsa ini harus dipikul bersama seluruh elemen bangsa, bukan saja dipikul oleh segelintir kalangan atau bahkan pemerintahan secara spesifik. Memenangkan masa depan memerlukan cara dan strategi yang terencana. Dan kurikulum 2013 merupakan salah satu dari ratusan bahkan ribuan rencana lain yang harus dipikul secara kolektif oleh segenap pewaris bangsa ini.

Citibank research group (dalam Baswedan, 2013) menyebutan bahwa Indonesia diprediksi akan berada pada 7 besar negara dengan kekuatan ekonomi terbesar di dunia pada tahun 2030. Sedangkan pada tahun 2050 dari sumber yang sama, Indonesia diprediksi akan menempati posisi 4 besar negara dengan 
pertumbuhan ekonomi terbesar di dunia. Posisi tersebut menyetarakan Indonesia dengan negara-negara besar lainya, seperti dijelaskan dalam tabel berikut ini:

Tabel 1. World Top Largest Economies 2030 \& 2050

\begin{tabular}{|c|c|c|c|}
\hline $\mathbf{2 0 3 0}$ & Country & $\mathbf{2 0 5 0}$ & Country \\
\hline $\mathbf{1}$ & China & 1 & China \\
\hline $\mathbf{2}$ & US & 2 & India \\
\hline $\mathbf{3}$ & India & 3 & US \\
\hline $\mathbf{4}$ & Japan & 4 & INDONESIA \\
\hline $\mathbf{5}$ & Brazil & 5 & Nigeria \\
\hline $\mathbf{6}$ & Russia & 6 & Brazil \\
\hline $\mathbf{7}$ & INDONESIA & 7 & Russia \\
\hline $\mathbf{8}$ & Germany & 8 & Japan \\
\hline $\mathbf{9}$ & UK & 9 & Philippines \\
\hline $\mathbf{1 0}$ & France & 10 & UK \\
\hline
\end{tabular}

Sumber: Citibank Research group (dalam Baswedan, 2013)

Prediksi untuk kejayaan Indonesia di masa mendatang sangatlah mudah untuk dicapai bila ada itikad kolektif untuk berproses pada kemenangan tersebut. Pada tataran akademis, capaian atas kejayaan masa depan Indonesia bukanlah sesuatu yang mustahil apabila sektor pendidikan dicapai terlebih dahulu. Berpijak dengan konsep ini, sudah saatnya memang, kurikulum pendidikan Indonesia tidak lagi hanya berkutat untuk membangun sumber daya manusia Indonesia secara khusus, tapi lebih daripada itu, kurikulum pendidikan harus mampu menjawab tantangan global dan memenangkanya secara bersama-sama.

Perdebatan tentang pengembangan kurikulum sesungguhnya tidak hanya terjadi di Indonesia. Topik tentang pengembangan kurikulum bahkan sudah diperdebatkan sejak tahun 1987 di Inggris. Perdebatan tentang pengembangan kurikulum saat itu berkutat tentang arahan yang akan dituju dari proses pengembangan kurikulum nasional (Daugherty dan Owens, 2003). Suatu perubahan memang pasti akan memunculkan kontroversi baru, tida terkecuali juga terjadi di Indonesia. Perdebatan tentang pengambangan kurikulum 2013 menyita banyak perhatian begitu juga proses politik yang berlangsung pada tataran elit. 
Jika berefleksi dengan pengalaman Inggris tahun 1987 saat mengalami tahapan yang sama dengan yang dihadapi Indonesia berkaitan kurikulum nasional 2013 saat ini, Inggris saat itu dapat menuntaskan proses perubahan kurikulum nasionalnya saat proses politik sudah tuntas dilakukan. Daugherty dan Owens (2003) menjelaskan dalam tulisanya bahwa salah satu tahapan yang harus dilalui sebelum pengembangan kurikulum dapat tercapai adalah tuntasnya proses politik nasional di Inggris saat itu. Pada konsep tersebut, sebenarnya ada poin penting yang bisa diambil dari perdebatan tentang pro dan kontra pengembangan kurikulum 2013. Pertama, pada tataran politik elit, pemerintah dalam hal ini harus menuntaskan dulu proses politiknya dengan legislatif. Kedua, pada tataran bawah, dinamika pengambilan kebijakan ini juga harus mengakomodir kebutuhan dan capaian kuriulum yang pada kurikulum sebelumnya harus disempurnakan lagi.

Dari beberapa uraian pendahuluan tersebut, dapat dirumuskan beberapa poin penting terkait gagasan awal penulisan makalah ini. Pertama, bahwa kemenangan masa depan Indonesia dalam persaingan global adalah sesuatu yang mungkin terjadi. Kedua, untuk dapat memenangkan pertarungan masa depan Indonesia, maka yang harus dikonstruksi dalam mindset segenap elemen bangsa adalah bagaimana menumbuhkan sikap optimisme bukan pesimistik negatif. Ketiga, memenangkan masa depan Indonesia buanlah sesuatu yang sulit, syaratnya perjuangan tersebut harus dilakukan secara kolektif dan progresif. Keempat, sekarang ini sudah saatnya melakukan pengembangan atau bahkan perubahan kurikulum untuk menjawab tantangan masa depan bangsa ini, dan kurikulum 2013 harus diarahkan untuk menjawab tantangan tersebut. Kelima, agar dapat melakukan pengembangan kurikulum secara mulus, yang paling utama dilakukan adalah dengan menuntaskan proses politik pada level elit nasional.

\section{PEMBAHASAN}

\section{Analisis Teoritik Pengembangan Kurikulum 2013}

Meminjam konsep teori Doerrer dan Pulley (1977) dalam sebuah tulisanya yang berjudul "The Politics of Curriculum Development" sangat 
menarik untuk dikutip tentang gagasan mereka yang menganggap pengembangan kurikulum sebagai sesuatu yang rasional dan proses yang sangat scientific. Pada konsep itu, makalah ini mencoba menyimpulkan bahwa sesungguhnya pengembangan kurikulum merupakan sesuatu hal yang sangat kodrati atau jika lebih ekstrim ditafsirkan, pengembangan kurikulum adalah sebuah keharusan. Dalam saat yang bersamaan, sudah jelas menjawab tentang logika berfikir yang berkembang saat ini yang menganggap pengembangan kurikulum sangatlah tidak efetif. Justru, pengembangan kurikulum adalah sebuah keharusan dan wajib hukumnya kurikulum mengikuti perkembangan zaman yang terjadi di era nya.

Sangatlah keliru anggapan yang ada saat ini, jika kurikulum yang terus berubah adalah bentuk ketidak konsistenan pemerintah dalam mengelola pendidikan nasional. Justru, jika meminjam konsep logika berfikir Doerrer dan Pulley (1977), kurikulum yang jarang berkembang adalah cerminan ketidak pekaan pemerintah dalam menjawab tantangan zaman dan kebutuhan peradaban di masanya. Lebih lanjut Doerrer dan Pulley (1977) menjelaskan, ada beberapa instrumen penting yang perlu menjadi perhatian segenap pihak yang kemudian dipinjam untuk menganalisis kebutuhan kurikulum 2013 dalam makalah ini.

Pertama, kurikulum 2013 harus jelas merumuskan jawaban tentang pertanyaan kebutuhan (needs) dan tujuan (goals) sekolah. Kedua, kurikulum 2013 harus jelas menjawab permasalahan tentang seleksi input menuju sebuah lembaga pendidikan. Ketiga, urutan konten (content) materi maupun sub materi yang terkandung dalam kurikulum 2013 harus mampu mengakomodir tidak saja dalam menjawab tantangan secara global, tetapi juga mampu merangkul kepentingankepentingan lokal baik itu yang berkaitan dengan local wisdom maupun keberagaman kebudayaanya.

Keempat, kurikulum 2013 menurut Doerrer dan Pulley (1977) harus mampu diorganisir (organization) secara holistik, artinya kurikulum 2013 tidak boleh matang secara konsep dan filosofis, tapi praktek yang terjadi di lapangan tidak pernah tertransformasi secara baik. Kekhawatiran ini juga yang menjadi pertimbangan oleh pihak-pihak yang menolak adanya pengembangan kurikulum 2013. Kelima, evaluasi (evaluation), aspek ini juga harus menjadi pertimbangan 
yang perlu dimasukkan dalam mensukseskan kurikulum 2013. Karena, pendekatan klasik yang berkaitan dengan sebuah proses pengembangan adalah bagaimana tahapan akhir (evaluasi) dari rangkaian proses itu dilakukan. Termasuk juga, kontroversi tentang pelaksanaan ujian nasional bisa menjadi bahan renungan dalam pelaksanaan kurikulum 2013 ini.

Model pengembangan kurikulum yang digunakan sebagai landasan teori makalah ini adalah model yang ditawarkan oleh Doerrer dan Pulley (1977). Secara singkat model tersebut dijelaskan dalam gambar berikut ini.

\section{Gambar 1. The Politics of Curriculum Development Model}

\section{CURRICULUM DEVELOPMENT PROCESS}

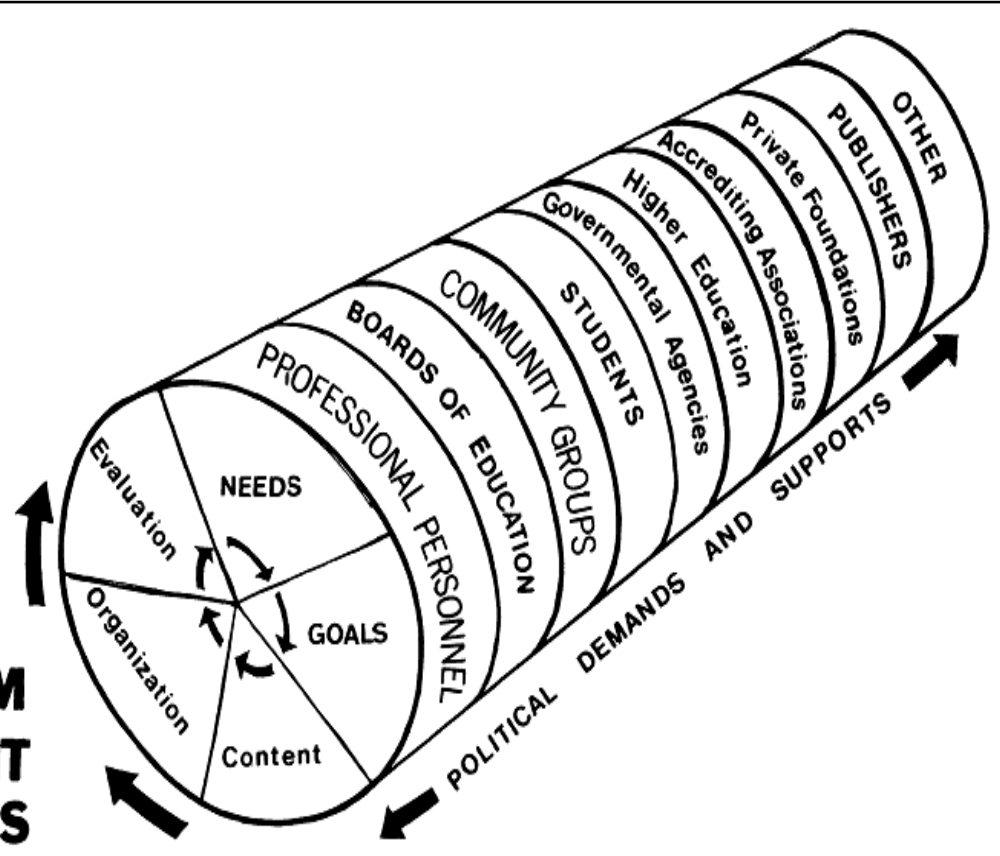

Sumber: Doerrer dan Pulley (1977)

Pengikut teori model ini menganut bahwa pengembangan kurikulum merupakan sebuah proses politik. Pengembangan kurikulum tak bisa dinafikkan, sangat membutuhkan apa yang disebut sebagai political dimension. Pengembangan kurikulum tidak akan pernah tercapai apabila proses politiknya belum tuntas. Sehingga, pada poin ini, kurikulum 2013 bisa dapat cepat terlaksana apabila proses politiknya sudah tuntas dilakukan. Ada beberapa pihak yang harus 
dirangkul dalam merumuskan bagaimana pengembangan kurikulum bisa dilakukan, yaitu kalangan profesional, pelaku pendidikan, kelompok komunitas, peserta didik, agen-agen pemerintah, lembaga pendidikan tinggi, asosiasi akreditasi, lembaga-lembaga yayasan swasta, dan media massa. Konsep besar yang menjadi variabel utama dalam proses pengembangan kurikulum yaitu, kebutuhan (needs), capaian (goals), konten (content), organisasi (organization), dan evaluasi (evaluation).

\section{1) Needs (Kebutuhan)}

Mengembangkan kurikulum secara periodik dan terus menerus merupakan salah satu kewajiban penanggung jawab pendidikan di sebuah negara (Doerrer dan Pulley, 1977). Asumsi itu, dibangun atas dasar bahwa untuk memenuhi kebutuhan masyarakat terdidik di suatu negara, maka sudah menjadi kewajiban untuk mereduplikasi kebutuhan tersebut dalam sebuah formulasi kurikulum. Alur berfikir yang muncul dengan logika tersebut, maka dapat diurai secara general, apa saja variabel yang menjadi kebutuhan untuk memenuhi adanya jumlah masyarakat terdidik di suatu bangsa. Kemdikbud (2012) menjelaskan ada empat variabel pokok yang menjadi kebutuhan mendasar yang harus dijawab oleh sebuah formulasi kurikulum yang baru. Kelima variabel tersebut yaitu, pertama, informasi. Informasi di era cyber saat ini merupakan sesuatu hal yang sangat lumrah dan sangat mudah untuk diakses. Sehingga, tuntutan zaman dan era mendatang, memang mengharuskan negara untuk mempersiapkan masyarakatnya untuk siap menjadi bagian dari mekanisme global tersebut. Informasi di era cyber saat ini, meruntuhkan batasan ruang dan waktu.

Kedua, komputasi, dengan memanafaatkan komputer sebagai mesin pembantu dan mempermudah pekerjaan manusia, maka tuntutan masyarakat terdidik secara teknologi menjadi pertanyaan rumit yang harus sesegara dijawab dalam sebuah formulasi kurikulum. Kebutuhan untuk memenuhi masyarakat yang "melek" teknologi adalah tantangan yang harus dijawab pemangku kebijakan pendidikan di Indonesia. Sehingga, mekanisme kerja konvensional semakin ditinggalkan untuk memenuhi tuntutan efektifitas dan efisiensi. 
Gambar 2. Pergeseran Paradigma Belajar di Abad 21

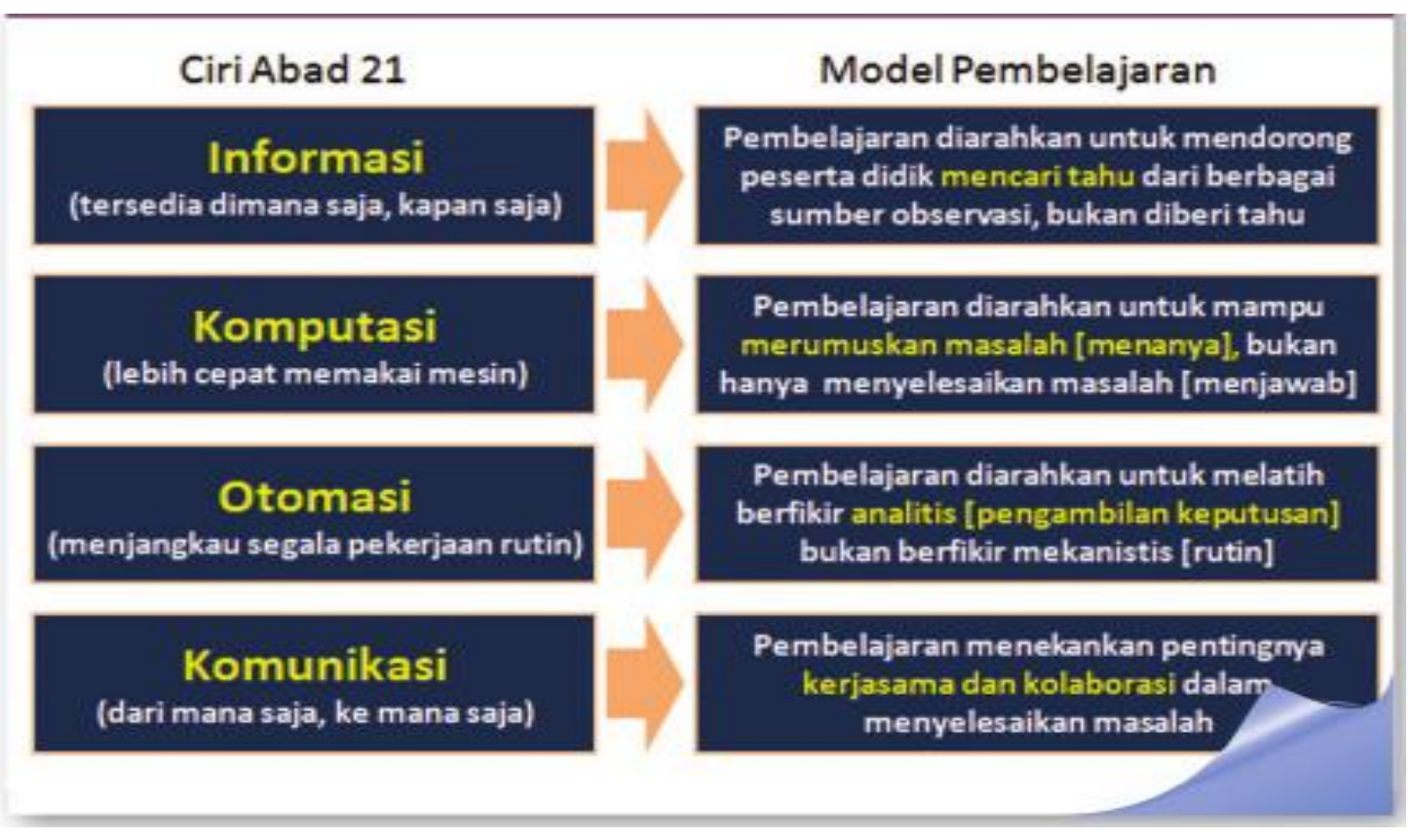

Sumber: Kemdikbud (2012)

Ketiga, paradigma belajar Otomasi, maksudnya adalah sebuah kurikulum nasional harus mampu menjangkau segala pekerjaan rutin dan dapat memenuhi pasar kerja yang menjadi objek kompetisi sebagian besar tenaga kerja terdidik. Dari cara berfikir yang demikian ini sebenarnya ada semacam pergeseran model belajar yang harus dibangun. Model pembelajaran seharusnya diarahkan untuk melatih berfikir analitis khususnya dalam mengambil keputusan secara cepat dan tepat. Pergeseran cara berfikiri inilah yang menjadi salah satu rekonseptualisasi berfikir yang ditawarkan dalam substansi gagasan di makalah ini. Kuriulum 2013 mengharuskan peserta didik untuk mampu berfikir keluar dari mainstream yang rutin dan terkesan konstan.

Keempat, komunikasi, tuntutan selanjutnya yang perlu dijawab adalah bagaimana membentuk peserta didik yang mampu bekerjasama dan berkolaborasi dalam menyelesaikan masalah. Variabel keempat ini sekaligus menjadi variabel yang mengisyaratkan tentang perlunya mekanisme kerja secara bersama untuk meminimalisir masyarakat yang individualistis. Kebutuhan untuk menghasilkan 
masyarakat terdidik yang mampu bekerjasama adalah salah satu masalah yang perlu dijawab dalam kurikulum 2013. Sehingga, sudah jelas bahwa kebutuhan pokok dalam menjawab berbagai tantangan di masa mendatang adalah sebuah keharusan untuk dijawab.

\section{2) Tujuan (Goals)}

Ada banyak pendekatan yang bisa digunakan untuk mengurai bagaimana seharusnya tujuan kurikulum itu diformulasikan. Namun, dalam makalah ini, pendekatan yang digunakan adalah pendekatan politik pengembanagan kurikulum sebagai strategi untuk memenangkan masa depan Indonesia. Kurikulum 2013 dirancang untu mampu menjawab tantangan di masa yang akan datang. Tantangan itu adalah tantangan yang bisa memenangkan masyarakat terdidik Indonesia untuk tidak saja mampu bersaing secara global, tetapi juga mampu memainkan peran dalam kompetisi tersebut. Secara umum, tujuan tersebut sudah jelas, bahwa memang sesungguhnya kurikulum 2013 bisa ditafsirkan sebagai instrumen untuk memenangkan masa depan Indonesia. Makalah ini juga menganggap bahwa kemenangan itu adalah sebuah proses panjang yang menjadi bagian parsial yang sangat panjang dari sebuh proses pengembangan kurikulum 2013.

Appleton, Lawrenz, Craft, Cudmore, Hall dan Waintraub (2007) menjelaskan bahwa pengembangan kuirikulum betujuan untuk membangun kurikulum yang tidak saja hanya memenuhi kebutuhan akan pengembangan ilmu pengetahuan yang sesuai dengan bidang keilmuanya, tetapi juga mampu bermanfaat bagi kebutuhan pasar global. Konstruksi konsep yang dibangun adalah adanya pengetahuan dan skill yang multidisipliner. Perumusan tujuan dirasa perlu dilakuan di awal pengembangan kurikulum, karena dalam beberapa model pengembangan kurikulum, sudah jelas digambarkan bagaimana sesungguhnya tujuan adalah poin paling pokok untuk mengarahkan bagaimana dan kemana arah pengembangan kurikulum itu diarahkan. Selain itu, tujuan yang dimaksudkan dalam penulisan ini tidak saja mencakup pengembangan kurikulum secara pragmatis, tetapi berusaha mengakomodir adanya dua pendekatan (pragmatis dan idealis) untuk melakukan pengambangan kurikulum. 


\section{3) Konten (Content)}

Berjalan pada konsep pengembangan kurikulum sebagai instrumen untuk memenangkan masa depan Indonesia, perlu difahami bagaimana konten dari kurikulum 2013 itu dikembangkan. Mengutip apa yang dijelaskan oleh Kemdikbud (2012), ada beberapa elemen penting yang menjadi perhatian pokok yang harus difahami.

\section{Gambar 3. Elemen Perubahan Kurikulum 2013}

\begin{tabular}{|c|c|c|c|c|}
\hline \multirow{2}{*}{ Elemen } & \multicolumn{4}{|c|}{ Deskripsi } \\
\hline & SD & SMP & SMA & SMK \\
\hline $\begin{array}{c}\text { Proses } \\
\text { Pembelajaran }\end{array}$ & \multicolumn{4}{|c|}{$\begin{array}{l}\text { - Penilaian berbasis kompetensi } \\
\text { - Pergeseran daripenilaian melalui tes (mengukur kompetensi pengetahuan } \\
\text { berdasarkan hasil saja), menuju penilaian otentk (mengukur kompetensi } \\
\text { sikap, keterampilan, dan pengetahuan berdasarkan proses dan hasil) } \\
\text { - Memperkuat PAP (Penilaian Acuan Patokan) yaitu pencapaian hasil } \\
\text { belajar didasarkan pada posisi skor yang diperolehnya terhadap skor } \\
\text { ideal (maksimal) } \\
\text { - Penilaian tidak hanya pada level KD, tetapi juga kompetensi int dan SKL } \\
\text { - Mendorong pemanfaatan portbfolio yang dibuat siswa sebagai instrumen } \\
\text { utama penilaian }\end{array}$} \\
\hline Ekstrakurikuler & $\begin{array}{l}\text { - Pramuka (wajib) } \\
\text { - UKS } \\
\text { - PMR } \\
\text { - Bahasa Inggris }\end{array}$ & \multicolumn{3}{|c|}{$\begin{array}{l}\text { - Pramuka (wajib) } \\
\text { - OSIS } \\
\text { - UKS } \\
\text { - PMR } \\
\text { - DIl } \\
\text { - Perlunya ekstra kurikuler partisipasi aktif } \\
\text { siswa dalam permasalahan kemasyarakatan } \\
\text { (menjadi bagian dari pramuka) }\end{array}$} \\
\hline
\end{tabular}

Sumber: Kemdikbud (2012)

\section{4) Organisasi (Organization)}

Meminjam teori oleh Doerrer dan Pulley (1977) tentang pengorganisasian kurikulum, menjadi menarik untuk mengetahui bagaimana Kurikulum 2013 menjadi instrumen penting dalam pembentukan masyarakat terdidik yang perlu diorganisir secara komprehensif. Ada beberapa dampak yang bisa ditimbulkan dari implementasi Kurikulum 2013 seperti dijelaskan Kemdikbud (2012) pada gambar berikut ini. 
Gambar 4. Dampak Pengembangan Kurikulum 2013

\begin{tabular}{|c|c|c|}
\hline No. & Entitas Pendidikan & Perubahan yang Diharapkan \\
\hline 1 & Peserta Didik & Lebih produktif, kreatif, inovatif, afektif \\
\hline 2 & $\begin{array}{l}\text { Pendidik dan Tenaga } \\
\text { Kependidikan }\end{array}$ & $\begin{array}{l}\text { Lebih bergairah dalam mengajar } \\
\text { Lebih mudah dalam memenuhi ketentuan } 24 \text { jam per minggu }\end{array}$ \\
\hline 3 & $\begin{array}{l}\text { Manajemen } \\
\text { Satuan } \\
\text { Pendidikan }\end{array}$ & $\begin{array}{l}\text { Lebih mengedepankan layanan pembelajaran termasuk } \\
\text { bimbingan dan penyuluhan } \\
\text { Antisipasi atas semaraknya variasi kegiatan pembelajaran }\end{array}$ \\
\hline 4. & $\begin{array}{l}\text { Negara dan } \\
\text { Bangsa }\end{array}$ & $\begin{array}{l}\text { Meningkatkan reputasi intemasional dalam bidang pendidikan } \\
\text { Meningkatkan daya saing } \\
\text { Berkembangnya Peradaban Bangsa }\end{array}$ \\
\hline 5 & Masyarakat Umum & $\begin{array}{l}\text { Memperoleh lulusan seokah yang kompeten } \\
\text { Kebutuhan pendidikan dapat dipenuhi oleh sekolah } \\
\text { Dapat meningkatkan kesejahteraannya }\end{array}$ \\
\hline
\end{tabular}

Sumber: Kemdikbud (2013)

\section{5) Evaluasi (Evaluation)}

Stobart (2001) menjelaskan bahwa substansi dari evaluasi sebuah kurikulum harus mengacu kepada kinerja dan aspirasi oleh guru sebagai pelaksana kurikulum tersebut. Evaluasi kurikulum harus mengacu tentang bagaimana seharusnya kurikulum bisa dijelaskan dalam perspektif pelaksananya. Mengevaluasi kurikulum juga harus memasukkan aspek politik dan intervensi pendidikan dalam membentuk bagaimana seharusnya kurikulum tersebut bisa dijelaskan dengan metode yang rinci. Melakukan evaluasi terhadap sebuah kurikulum bukan proses yang pendek, tetapi membutuhkan kebersinambungan evaluasi yang dilakuan secara terus menerus. Daugherty (1995) dan Black (1998) dalam (Stobart, 2001) sudah sangat jelas mengatakan bahwa evaluasi kurikulum harus memasukkan penilaian kinerja guru sebagai salah satu indikatornya. Artinya, jika kinerja guru belum bisa memenuhi tuntutan zamn oleh mekanisme kerja kurikulum yang sudah ada, maka sudah menjadi keharusan untuk melakukan pengembangan kurikulum selanjutnya. 
Framework yang digunakan dalam makalah ini yaitu konsep dimensi politik. Dalam dimensi politik, keberpihakan kurikulum 2013 sebagai instrumen untuk membentuk karakter peserta didik di masa mendatang adalah dengan memanfaatkan kurikulum ini sebagai strategi untuk membawa masyarakat terdidik kepada arah pengembangan sumber daya manusia terdidik. Ada dua pendekatan dalam perspektif politik untuk menterjemahkan bagaimana seharusnya menterjemahkan kurikulum 2013 sebagai instrumen pemenangan masa depan Indonesia. Pertama, Shepard (1993, dalam Stobart, 2001) menjelaskan bahwa kurikulum 2013 harus diarahkan sebagai sebuah konsep yang terintegrasi. Dengan memaknai Kurikulum 2013 sebagai sebuah konsep yang terintegrasi, maka bisa disimpulkan apa yang disampaikan oleh Shepard (1993, dalam Stobart, 2001) bahwa Kurikulum 2013 harus mampu memasukkan berbagai variasi konsep sebagai satu kesatuan wadah yang terintegrasi. Kedua, kurikulum 2013 harus mampu menjaga validitas di setiap jenjang pendidikan dengan memberlakukan standar pendidikan multi disiplin ilmu (Aera, 1985 dalam Stobart, 2001).

\section{Kemenangan Masa Depan Indonesia di Hadapan Kita}

Memenangkan masa depan Indonesia merupakan bagian dari substansi tujuan dalam penulisan makalah ini. Ada beberapa sektor kemenangan masa depan Indonesia yang sangat realistis untuk dicapai. Beberapa argumen akademik juga memungkinkan untuk republik ini sampai pada tujuan tersebut. Memenangkan masa depan Indonesia bukan sesuatu yang mustahil, kemenangan Indonesia sangat rasional dan logis. Sehingga, kesalahan besar jika hingga detik ini argumen pesimisme tentang kejayaan masa depan Indonesia masih berdering. Meminjam hasil analisis data oleh McKinsey dengan mengacu pada standar ekonomi yang digunakan oleh World Bank (dalam Radjasa, 2013) dipresiksi bahwa jumlah kelas menengah di Indonesia pada tahun 2020 meningkat menjadi 85 juta orang, jumlah tersebut meningkat 40 juta jika dibandingkan dengan jumlah kelas menengah di tahun 2010 yang berjumlah 45 juta orang. Jumlah kelas menengah akan terus meningkat menjadi 170 juta orang bila menggunakan 
skenario pertumbuhan ekonomi 7\%. Sedangkan, jika menggunakan skenario pertumbuhan ekonomi 5-6\%, maka jumlah kelas menengah di Indonesia meningkat menjadi 135 juta jiwa.

\section{Gambar 5.}

\section{Prediksi Jumlah Kelas Menengah di Indonesia Tahun 2020 dan 2030}

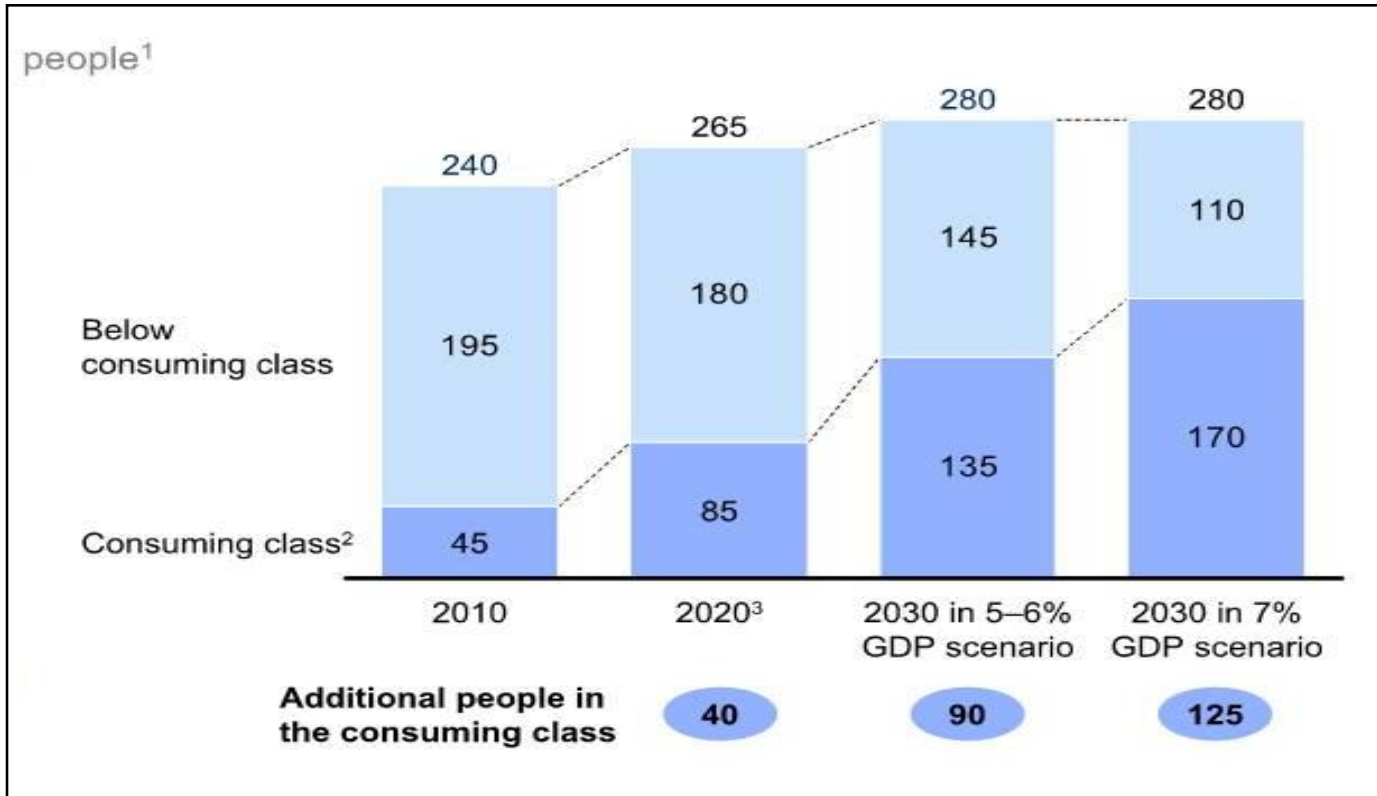

Sumber: McKinsey (dalam Radjasa, 2013)

Prediksi Mckinsey menggunakan standar kelas menengan versi world bank yang mengacu pada jumlah pengeluaran diatas US\$ 4. Prediksi McKinsey tersebut, menjadi bentuk keyakinan argumen dasar yang dibangun dalam penulisan makalah ini. Asumsi yang mendukung prediksi McKinsey tersebut, didukung oleh posisi Indonesia saat ini yang sudah menjadi anggota negaranegara G20, dimana Indonesia ditempatkan menjadi negara dengan kekuatan ekonomi pada 20 besar dunia. Secara spesifik, Indonesia menempati posisi 16 dari 20 negara (World Bank dalam Radjasa, 2013) dengan pertumbuhan ekonomi paling baik di dunia. Realita ini sekaligus meyakinkan bahwa Indonesia memiliki kekuatan ekonomi yang sangat besar dikemudian hari. Prediksi tentang Indonesia sebagai negara maju dalam sektor ekonomi menjadi argumen yang bisa dipertanggung jawabkan. 
Kemenangan masa depan Indonesia juga didukung oleh kondisi saat ini, kondisi dimana Indonesia merupakan negara dengan jumlah penduduk besar di dunia. Mengutip data dari United Nation Population Fund (dalam Baswedan, 2013) disebutkan bahwa pada tahun 2050, jumlah penduduk Indonesia diprediksi menjadi 296 juta dengan GDP per kapita sebesar \$22,000. Pada poin itu, maka bisa disimpulkan bahwa sesungguhnya besarnya jumlah penduduk Indonesia merupakan sebuah potensi besar yang sangat menguntungkan. Disaat bersamaan, argumen potensi tersebut, sekaligus mematahkan dan meruntuhkan argumen yang selama ini menganggap bahwa kepadatan dan ledakan penduduk merupakan sebuah ancaman dan masalah besar. Kekuatan Indonesia sebagai salah satu negara penggerak ekonomi dunia di masa mendatang, bisa dicapai apabila memanfaatkan momentum ini dengan melaksanakan politik pendidikan (pengembangan kurikulum) untuk mencapai tujuan dan prediksi-prediksi akademisi tentang kejayaan dan kemenangan masa depan Indonesia.

Pencapaian untuk memenangkan masa depan Indonesia di sektor pendidikan sebenarnya juga didukung oleh tren yang menunjukkan semakin meningkatnya jumlah sumber daya manusia terdidik. Semakin meningkatnya jumlah sumber daya manusia yang terdidik harus diciptakan skenario politik pendidikan untuk mau diarahan kemana besarnya jumlah orang-orang terdidik tersebut. Seperti dikutip dari data World Bank (dalam Nizam, 2013) disebutan bahwa jumlah manusia terdidik semakin hari semakin meningkat jumlahnya. Peningkatan jumlah manusia terdidik ini, apabila tidak diikuti dengan setting politik kurikulum yang mampu menjangkau masa depan, maka jumah yang semakin banyak jumlahnya itu justru akan menjadi ancaman bagi masa depan bangsa ini. 
Tabel 1. Tantangan Sumberdaya Manusia Terdidik

\begin{tabular}{|c|l|l|l|}
\hline Pendidikan & $\mathbf{2 0 0 1}$ & $\mathbf{2 0 0 6}$ & $\mathbf{2 0 1 0}$ \\
\hline SD/tidak tamat SD & $63.0 \%$ & $55.5 \%$ & $51.5 \%$ \\
\hline SMP & $17.7 \%$ & $20.2 \%$ & $18.9 \%$ \\
\hline SMA & $10.3 \%$ & $12.7 \%$ & $14.6 \%$ \\
\hline SMK & $5.5 \%$ & $6.2 \%$ & $7.8 \%$ \\
\hline Diploma I,II,III & $\mathbf{1 . 6 \%}$ & $\mathbf{2 . 2 \%}$ & $\mathbf{2 . 7 \%}$ \\
\hline Universitas & $\mathbf{1 . 8 \%}$ & $\mathbf{3 . 2 \%}$ & $\mathbf{4 . 6 \%}$ \\
\hline
\end{tabular}

Sumber: World Bank (dalam Nizam, 2013)

Senada dengan data tentang meningatnya jumlah manusia terdidik di setiap periodenya, data tentang jumlah penduduk di usia muda pada tahun 2020 juga menunjukkan adanya peningatan tajam. Diprediksi, pada tahun 2020, Indonesia akan mengalami apa yang disebut sebagai ledakan jumlah penduduk usia produktif. Itu artinya, besarnya potensi ini harus diikuti juga oleh skenario pemenangan masa depan yang gemilang ini. Ada semacam formulasi agenda skenario yang coba disimpulkan dalam penulisan makalah ini.

\section{Gambar 6. Formulasi Strategi Memenangkan Masa Depan Indonesia}

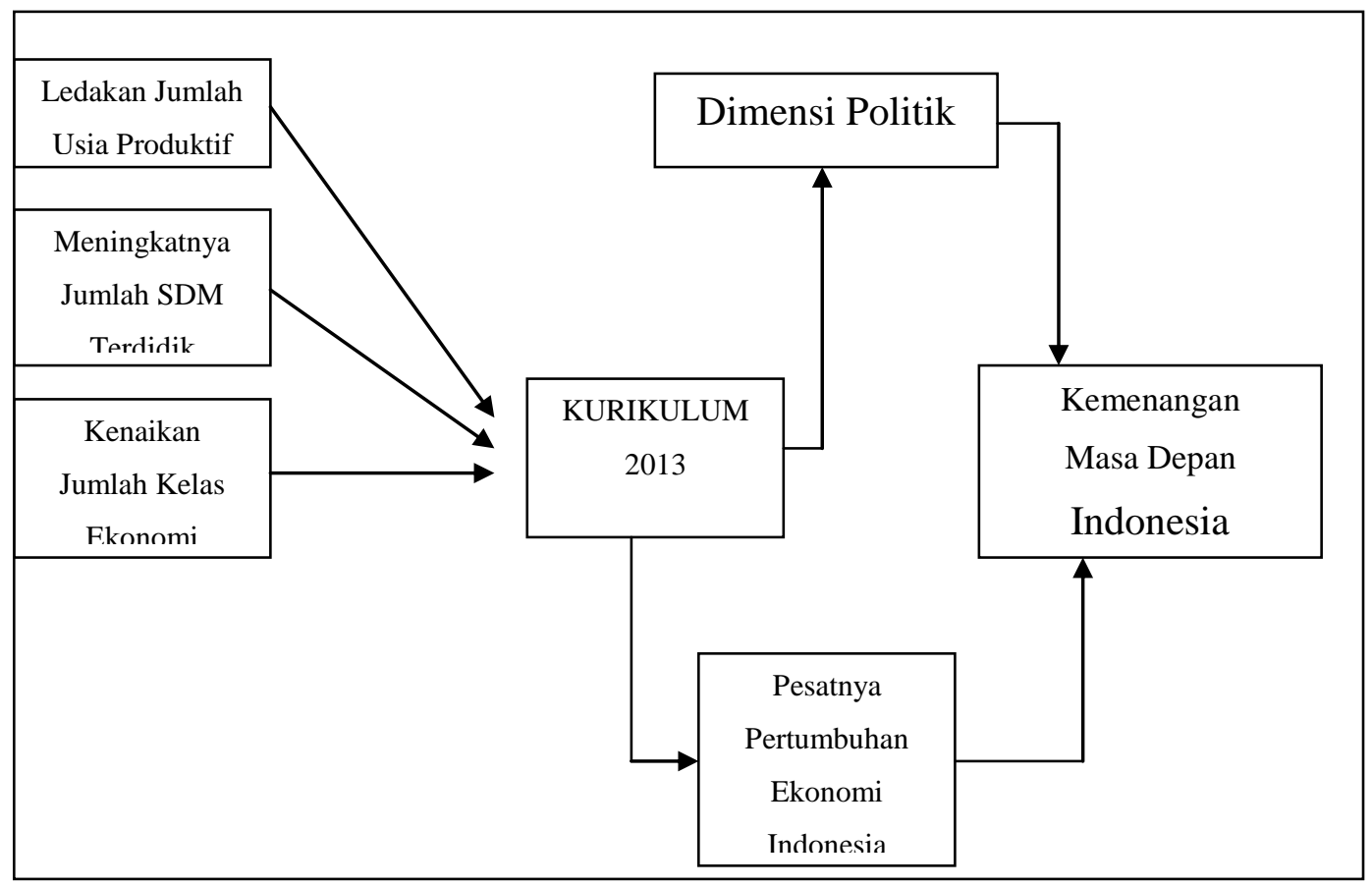


Gagasan inti dalam penulisan makalah ini sesungguhnya sedang mengkonstruksi formulasi berfikir yang menganggap Kurikulum 2013 merupakan instrumen kunci sebagai salah satu strategi agenda politik untuk memenangkan masa depan Indonesia. Dalam dimensi politik, konsolidasi beberapa variabel pendukung kemenangan kompetisi internasional sangatlah penting. Variabelvariabel yang dimaksudkan yaitu pertama, meledaknya jumlah usia produktif di Indoensia sebenarnya merupakan potensi sekaligus ancaman yang berjalan secara bersamaan. Untuk konteks politik pendidikan, besarnya jumlah usia produktif merupakan sebuah potensi yang sangat baik dimanfaatkan untuk membangun fondasi perkembangan masa depan republik ini. Besarnya jumlah usia produktif, bisa menjadi mesin penggerak konstruksi sosial, sektor-sektor mikro yang menurut banyak ahli sebagai sektor yang paling stabil di Indonesia, dianggap sebagai senjata politik untuk memasukkan Indonesia sebagai negara maju sejajar dengan negara besar saat ini.

Kedua, trend memingkatnya jumlah sumber daya manusia terdidik, harus dimanfaatkan sebagai mesin penggerak sektor pendidikan terutama redistribusi akses pendidikan kepada seluruh lapisan masyarakat. Besarnya jumlah sumber daya manusia terdidik sangat mungkin dimanfaatkan untuk membangkitkan sektor pendidikan khususnya membantu pengembangan ilmu pengetahuan secara langsung maupun tak langsung. Tidak bisa dinafikkan, adanya kebutuhan dan tuntutan perkembangan ilmu pengetahuan, teknologi, dan seni adalah sebuah upaya logis yang harus dijawab dalam goals (tujuan) dari pengembangan kurikulum 2013. Kurikulum 2013 dalam perspektif politik progresif, dianggap sebagai instrumen untuk memenangkan masa depan Indonesia. Strategi politik kurikulum memungkinkan adanya sinergitas antara pihak kelompok-kelompok masyarakat untuk membangun kekuatan baru dalam sektor-sektor seperti yang sudah disebutkan sebelumnya.

Ketiga, meningkatnya jumlah kelas ekonomi menengah dimanfaatkan sebagai kekuatan untuk membangun sektor ekonomi makro dan mikro yang bermanfaat untuk membangkitkan pertumbuhan ekonomi di Indonesia. Melimpahnya jumlah kelas ekonomi menengah merupakan potensi yang sangat 
bermanfaat untuk mengarahkan gerak pertumbuhan ekonomi secara kongkrit. Alasanya, kalangan kelas menengah ekonomi merupakan kalangan yang paling konsumtif dan kalangan yang jumlahnya besar. Kekuatan kelas menengah diharapkan mampu mengatrol kelas ekonomi lemah melalui tingkat konsumsi dan pajak yang merupakan setting politik paling ampuh untuk mendorong perekonomiam di Indoesia.

Tiga variabel itulah yang harus dikonsolidasikan secara politis untuk menjadi embrio kemenangan masa depan Indonesia. Namun, untuk mencapai kemenangan tersebut, ada semacam instrumen besar yang harus dipenuhi terlebih dahulu. Instrumen yang dimaksudkan dalam makalah ini yaitu Kurikulum 2013 sebagai sebuah kekuatan jembatan emas yang menghubungkan antara potensi besar dengan goals (tujuan) masa depan Indonesia. Untuk bisa mencapai kepada tahapan capaian kemenangan masa depan, Indonesia harus mengokohkan terlebih dahulu, bagaimana jembatan itu. Itulah sebabnya, konsensus kolektif segenap pemangku kepentingan pendidikan di Indonesia menjadi keharusan untuk membangun jembatan kemenangan masa depan Indonesia. Logika berfiir yang harus dibangun adalah kurikulum yang mampu menjawab kebutuhan zaman.

Menggunakan teori model Curriculum Development oleh Nygaard, Hojlt dan Hermansen (2008), Gagasan yang dibangun yaitu pengembangan kurikulum adalah bagaimana mengidentifikasi kebutuhan material kurikulum dalam menjawab kebutuhan masyarakat. Selanjutnya berkaitan tentang tenaga-tenaga terdidik dalam dunia kerja. Identifikasi ini bisa menjadi perdebatan dalam beberapa pendekatan terkait yang mana lebih berhak mengidentifikasi dan sektor mana yang paling relevan.

Perdebatan klasik antara penganut pendekatan konservatif dan penganut pendekatan progresif adalah bagaimana seharusnya pengembangan itu dilakukan. Bagi penganut faham konservatif, perubahan tidaklah seharusnya dilakukan secara masif dan menyeluruh. Yang terpenting adalah bagaimana perubahan tersebut cukup mendukung kondisi saat ini yang sudah dianggap mapan. Perubahan hanya dianggap sebagai pendukung kondisi lama yang mapan, tanpa perlu mengkoreksi hal-hal yang sudah dianggap stabil. Pengembangan dalam perspektif konservatif 
juga dimaknai sebagai sebuah pendukung keadaan yang sudah ada tanpa mengubah inti pokok dari kondisi mapan saat ini.

Di sisi lain, pengambangan bagi penganut pendekatan progresif justru dimaknai sebagai sebuah proses masif, menyeluruh, dan komprehensif. Pengembangan ini tidak saja hanya dimaknai sebagai sebuah penyempurna kondisi mapan yang sudah ada, tapi lebih daripada itu, pengembangan dimaknai sebagai sebuah perubahan besar bahkan hingga pada inti dari kondisi tersebut. Sehingga, untuk mendukung gagasan teori yang menjadi landasan pokok penulisan ini, saya cenderung untuk mendudukan tulisan ini sebagai sebuah konstruksi berfikir yang bersandar pada pendekatan progresif. Dimana, pengembangan tidak saja hanya sebagai penyempurna kondisi saat ini, tetapi juga untuk mendukung inti-inti dan proses dari pembentukan kurikulum tersebut.

Menurut Nygaard, Hojlt dan Hermansen (2008) tindakan paling pokok yang harus dilakukan oleh team pengembang kurikulum adalah membuat keputusan yang sistemik berkaitan tentang karakteristik peserta didik, evaluasi, metode, konten, dan capaian hasil. Pertama, karakteristik peserta didik merupakan indikator penting dalam memberikan perlakuan dan proses pencapaian tujuan kurikulum yang ingin dicapai. Karekteristik peserta didik juga menjadi indikator bagaimana cara berfikir kurikulum itu harus disesuaikan. Kedua, evaluasi, sebagai salah satu ukuran sukses atau gagalnya sebuah proses pelaksanaan kurikulum, adalah dengan melakuan evaluasi seberapa jauh proses kurikulum itu mampu memenuhi target capaian akhir dari kurikulum tersebut.

Ketiga, metode, aspek ini merupakan aspek yang juga penting sebagai tindak lanjut dari pelaksanaan kurikulum yang akan dijalankan. Pemilihan metode pelaksanaan kurikulum juga berhubungan erat dengan aspek pertama tadi, yaitu karakteristik sosial peserta didik. Asumsi yang saya bangun dalam tulisan ini, pemilihan metode yang dipilih oleh team pengembang kurikulum harus menyesuaikan karakteristik peserta didik tersebut. Bisa saja, perbedaan kultur setiap instansi daerah menjadi salah satu konsideran dalam menentukan metode mana yang akan dipilih. 
Keempat, konten, aspek ini menjadi aspek yang sangat penting untuk menentukan bagaimana arah pengambangan kurikulum itu dibidik. Seringkali, pengembangan kurikulum cenderung hanya membidik kebutuhan pasar kerja, sehingga mengabaikan aspek-aspek yang juga penting yaitu aspek konten dari kurikulum tersebut. Kurikulum diharapkan mampu memberikan konten yang tidak saja mampu menjawab kebutuhan pasar, tapi kurikulum juga mampu memberikan konten untuk mengembangkan keilmuwan saat ini.

Dengan merujuk pada konten yang didefinisikan sebagai aspek terintegrasi dalam penyusunan, maka secara otomatis mampu membentuk bagaimana capaian hasil luaran yang diinginkan dari kurikulum tersebut. Adanya capaian hasil luaran ini merupakan aspek kelima dalam konsideran yang harus dipertimbangkan oleh team pengambang kurikulum. Aspek ini juga perlu dikaji dengan kajian lulusan untuk mengetahui seberapa jauh relevansi kurikulum tersebut dengan hasil luaran yang sudah ada.

\section{PENUTUP}

Pada akhirnya, makalah ini sedang menuju pada kesimpulan bahwa adanya kebutuhan perkembangan zaman dan kebutuhan pasar global mengharuskan Indonesia juga harus mengikuti perngembangan-pengembangan di berbagai sektor. Khusus untuk sektor pendidikan, pengembangan kurikulum adalah tuntutan wajib yang harus dipenuhi sebagai prasyarat untuk mencapai kemenangan masa depan Indonesia. Kurikulum 2013, tidak saja hanya dimaknai sebagai sebuah proses tambal sulam proses pendidikan secara praktis. Tapi lebih daripada itu, Kurikulum 2013 dapat dimaknai sebagai agenda politik jangka panjang yang diarahan untuk menggiring masa depan Indonesia yang sejajar dengan bangsa-banga maju yng ada saat ini. Sehingga, logikanya akan terbalik, Kurikulum 2013 justru dimaknai sebagai kebutuhan buan keharusan. Konsep logika kebutuhan tentang pengembangan kurikulum 2013 menjadi suplemen yang paling mujarap untuk strategi yang disebut sebagai cara untuk "Memenangkan Masa Depan Indonesia”. 


\section{DAFTAR PUSTAKA}

Appleton, James. Lawrenz, Frances. Craft, Elaine. Cudmore, Wynn. Hall, Jim. dan Waintraub, Jack. 2007. Models for Curricular Materials Development: Combining Applied Development Processes with Theory. Source: Journal of Science Education and Technology, Vol. 16, No. 6 (Dec., 2007), pp. 491-499. Published by: Springer. Stable URL: http://www.jstor.org/stable/40188621. Accessed: 28/05/2013 22:23.

Baswedan, Anies. 2013. Projecting Indonesia. Power point Presentasi pada acara Presidential Lecture Series Dies Natalis 70 Universitas Islam Indonesia. Yogyakarta.

Daugherty, Richard dan Owens, Prydwen Elfed. 2003. A National Curriculum for Wales: A Case Study of Education Policy-Making in the Era of Administrative Devolution. Source: British Journal of Educational Studies, Vol. 51, No. 3 (Sep., 2003), pp. 233-253. Published by: Taylor \& Francis, Ltd.on behalf of the Society for Educational Studies. Stable URL: http://www.jstor.org/stable/1555870. diakses pada: 05/06/2013 01:00.

Doerrer, Paul W. dan Pulley, Jerry L. 1977. The Politics of Curriculum Development. Source: The Clearing House, Vol. 50, No. 6 (Feb., 1977), pp. 260-261. Published by: Taylor \& Francis, Ltd. Stable URL: http://www.jstor.org/stable/30184897. Diakses pada: 28/05/2013 22:45.

Kemdikbud. 2012. Sosialisasi Kurikulum 2013. Diakses dari: http://www.kemdiknas.go.id/kemdikbud/. Pada tanggal 25 Juni 2013.

Nizam. 2013. Reformasi Pendidikan Tinggi di Indonesia. Presentasi Sekretaris Dewan Pendidian Tinggi. Universitas Gadjah Mada. Yogyakarta.

Nygaard, Claus. Hojlt, Thomas. dan Hermansen, Mads. 2008. Learning-Based Curriculum Development. Source: Higher Education, Vol. 55, No. 1 (Jan., 2008), pp. 33-50. Published by: Springer. Diakses dari: http://www.jstor.org/stable/29735162. pada tanggal: 28/05/2013 21:30.

Radjasa, Hatta. 2013. Mengoptimalkan Peran Kelas Menengah dalam Perekonomian. Presentasi disampaikan pada acara diskusi yang diselenggarakan majalah prisma. Jogjakarta, 08 maret 2013.

Stobart, Gordon. 2001. The Validity of National Curriculum Assessment. Source: British Journal of Educational Studies, Vol. 49, No. 1 (Mar., 2001), pp. 2639. Published by: Taylor \& Francis, Ltd.on behalf of the Society for Educational Studies. Stable URL: http://www.jstor.org/stable/3122058. Accessed: 28/05/2013 21:45.

World Bank. 2012. World Development Indicator. Diakses dari http://databank.worldbank.org/data/views/reports/chart.aspx. Pada tanggal $\underline{5 \text { Juni } 2013}$. 